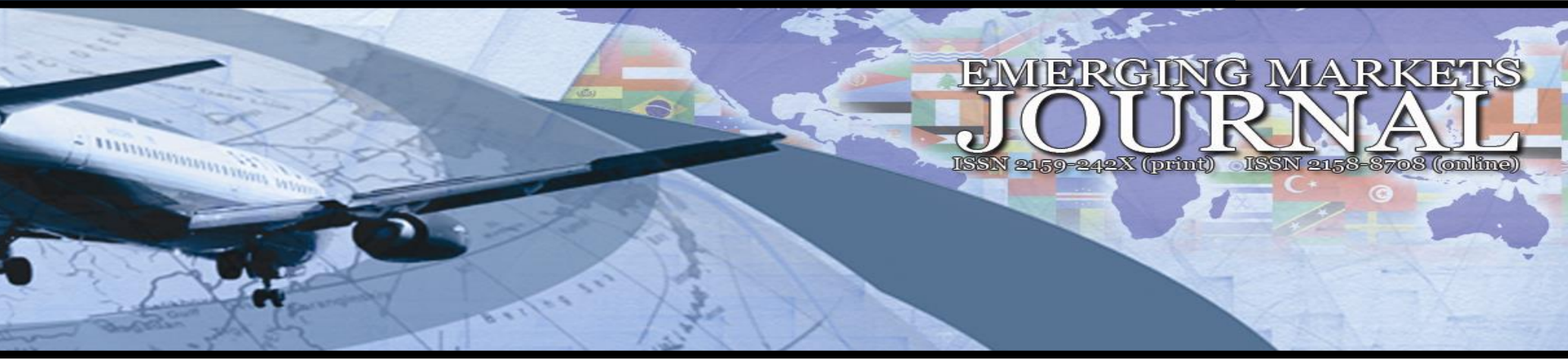

\title{
Quality of Life and Quality of Work Life as Determinants of Employee Productivity: Self-reports of Tea Harvesters in Sri Lanka
}

\author{
Anuruddha Gamage \\ Kelani Valley Plantations PLC - Hayleys Plantations Sector, Sri Lanka | e-mail: anuruddha.gamage@kvpl.com
}

\section{Widana Pathiranage Richard Wickramaratne}

University of Peradeniya, Sri Lanka | e-mail: wp_richard@yahoo.com

Volume 11 No 1 (2021) ｜ ISSN 2158-8708 (online) ｜ＤOI 10.5195/emaj.2021.217 | http://emaj.pitt.edu

\begin{abstract}
Tea industry plays a prominent and strategic role in Sri Lanka due to its significant impact on national output, employment and socio-economic status. Therefore, the overall worker productivity in tea industry plays an integral role in terms of national income and foreign exchange earnings. Today, the tea industry in Sri Lanka has been facing the burning issue of declining worker productivity which is the lowest among the tea producing countries in the world. In order to increase the level of worker productivity, simply applying conventional Human Resource Management (HRM) practices is not adequate and a sustainable HRM model is a vital requirement as a strategy for dealing with this crisis and sustains the tea industry in the competitive global marketplace. This research was aimed at proposing human care practices (HCPs) and knowledge management practices (KMPs) as sustainable Human Resource Management Practices (SHRMPs) for enhancing the worker productivity through quality of work-life (QWLs) and quality of life (QLs). The study is specifically focusing on the tea industry, since tea is the key contributor for overall performances of the plantation industry. Un-structured and one-on-one interviews were used as the qualitative research technique for this study. 100 randomly selected tea harvesters who are working in well performing tea estates in Sri Lanka reported a list of HCPs and KMPs that enhance QWL and QL, which in return enhance the worker productivity. The responses of tea harvesters were grouped into pre-defined structure according to comparative importance and then were validated with the findings of previous research studies. The findings were well supported by the premises of psychological contract and social exchange theories. The study also provides some implications for policy decisions and future research directions on identified HCPs and KMPs as sustainable HR practices, which has a direct relationship on the worker productivity.
\end{abstract}

Keywords: Sustainable Human Care Practices, Knowledge Management Practices, Quality of Life, Quality of Work Life, Productivity

\section{(c) $\mathrm{EY}$}

New articles in this journal are licensed under a Creative Commons Attribution 3.0 United States License.

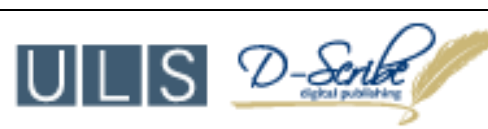

This journal is published by the University Library System of the University of Pittsburgh as part

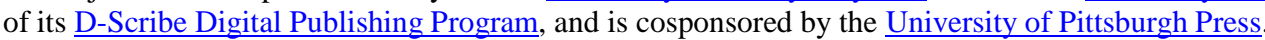




\section{Quality of Life and Quality of Work Life as Determinants of Employee Productivity: Self- reports of Tea Harvesters in Sri Lanka}

\author{
Anuruddha Gamage \\ Widana Pathiranage Richard \\ Wickramaratne
}

\section{Introduction}

Tea is the most consumed beverage in the world apart from water and the demand for consumption of tea will remain unchanged for the near future as well (Tea Review - Forbes and Walker, 2019). Therefore, the plantation industry is undoubtedly a critical context in the socio-economic make up in Sri Lanka (Koththagoda and Dissanayake, 2017).The tea industry is found as a major partner for more than a century in Sri Lanka's economy in terms of foreign exchange earnings, national output and employment. Sri Lanka's best opportunity in sustaining the tea sector is strengthening the unique brand of 'Pure Ceylon Tea' in order to be competitive in the global market. The global competitiveness in tea will increase with the quality of product and the profitability of suppliers, which is applicable to Sri Lanka as well. The country can also raise earnings from tea by integrating deeper into the global value chain. This can be achieved by increasing the share of value added tea production and exports. In order to achieve the competitive edge from the global competitiveness in the industry, cost of production is a critical limiting factor. In regards to managing the cost, practical approach is to enhance worker productivity from raw material producer. Furthermore, wages account for up to $80 \%$ of input costs for the tea industry. Labor pricing, combined with lower productivity, is putting Sri Lankan growers at a disadvantage in the global market (Oxford Business Group, 2016).

In terms of worker productivity in tea industry, Sri Lanka is facing serious issues on declining productivity (Munasinghe et al., 2017), which recorded the lowest productivity amongst the tea producing countries (Kelegama, 2010, Perera, 2017). The ultimate impact of declining productivity in Sri Lankan tea industry, combined with rising input costs, have led to declining overall profitability (Hilal, 2020) and created serious socio-economic challenges interrupting the sustainable growth of industry (Gamage and Wickremeratne, 2019). It is argued that, lapses in management and higher overhead cost have a significant impact on declining productivity, which resulted in negative consequences on social and environmental aspects (Wal, 2018). Therefore, Sri Lanka needs to change traditional land, labor usage and management models applicable specially on respect of Regional Plantation Companies (RPCs), to enable RPCs to solve the current crisis of tea industry, mainly due to declining worker productivity and low yield, which ultimately leads to low profitability in the industry (Dishanka and Ikemoto , 2014; Koththagoda and Dissanayake, 2017). Low financial performances of the tea industry, created a situation of decreasing investment on providing social and human facilities. Dishanka and Ikemoto (2014) further stressed the imbalance of bidirectional cycle of social development of tea plantation workers and productivity, which declining productivity will lead to low attention on social development initiatives. On the other hand, findings of Mwaura and Muku (2007) suggested that in order to improve the labor productivity, the welfare of farmers should be improved in the tea plantation industry. They further elaborated that inadequate human care initiatives, poor socioeconomic condition of workers, non-competitive \& traditional work norms, lack of cooperativeness between workers and management have adversely affected the labor productivity. Omotoyo (2015) further added that, inadequate attention to knowledge management initiatives will lead to a decline in productivity as well.

It has been identified from previous research that, different human resource management approaches aiming at uplifting the workers' social status and activities related to increase the social well-being of workers, contributed positively in increasing worker productivity levels of tea plantation workers from the present levels (Dishanka and Ikemoto, 2014; Savarimuthu and Rachael, 2017; Gamage and Wickramaratne, 2018; Gamage and Wickramaratne, 2019). This fact was well supported with the findings of Munasinghe et al. (2017) that, worker benefits to increase their reputation, wage structure matches with present living conditions and fair wages and upgrading living facilities will increase worker satisfaction and loyalty. These will eventually result in increased productivity and reduced production costs.

In sum, above challenges and issues implies that the existing traditional Human Resource Management (HRM) policies and practices in the tea plantation industry in Sri Lanka are not sufficient for dealing with the problem of low worker productivity and its negative consequences on socio-economic parameters. Therefore, the overarching purpose of this study is to further verify findings of prior study conducted by the authors based on the perceptions of different managerial levels in tea industry. Another aim of this research is to identify productivity enhancing human care and knowledge management practices and to propose a productivity enhancing HRM model applicable for sustainable tea plantation industry. Study also attempts to further expand the attention of planation companies, even to execute critical decisions to invest on human care and knowledge management practices as sustainable human resource management initiatives in the tea estates, which has an impact on improving the level of quality of life (QL) and quality of work-life (QWL) of workers in the estates. Study further validates with the results that uplifting QWL and QL has a direct impact on increasing the level of productivity. 


\section{Literature Review}

Traditional agriculture set-up which had been continuing for centuries was replaced by large scale plantation agriculture in the mid-18th century, introducing tea for commercial cultivation in 1876 (Tea Research Institute of Sri Lanka, 2016). With the introduction of commercial tea cultivation, unique social division was emerged due to migrant workers, especially from south India. Since then, the tea sector is socially important as these resident workers have been geographically and socially isolated from the other sectors of the economy for over 150 years (Jayawardena, 1984). This social divisions and migrant nature of tea plantation workers have contributed to the economic and social exclusion of tea plantation workers (Lahiri, 2000). Although the contribution of agriculture sector in to the economy of Sri Lanka is significant for the last few decades, a sharp decline has been identified over the last few years. Currently, the contribution of agriculture in country's Gross Domestic Product (GDP) is recorded as low as $7.87 \%$ in 2018 (Department of Census and Statistics- Sri Lanka, 2019). It is highlighted that, tea as the main plantation crop in Sri Lanka has recorded one of the lowest contributions in country's GDP as it was recorded as $0.78 \%$ for 2018 (Central Bank of Sri Lanka, 2018).

Irrespective of the contribution of tea industry towards Sri Lanka's economy in terms of GDP, industry continues to occupy a pivotal position in terms of foreign exchange earnings \& employment. Tea export earnings, in terms of revenue, realized 184.7 billion rupees recording a growth 2.7 billion rupees compared to 2015 (Central Bank of Sri Lanka, 2018). In terms of employment, 2 million people were employed directly \& indirectly which highlights $10 \%$ of the population of Sri Lanka depending on the industry (Department of Census and Statistics, 2019). Also, Sri Lanka is one of the top four tea producers in the world, ranking at the top with India, China and Kenya, which all are much larger countries (Silva, 2018). Although Sri Lanka is one of the major tea producing countries in the world, unlike other major producers, approximately $90 \%$ of the tea production is exported to world markets (Hilal, 2020). It expressed that, tea is a desired commodity by its very nature, crosses international boundaries, hence act as one of the main contributor for socio-economic performance of Sri Lanka irrespective of various challenges (Gamage and Wickremaratne, 2019). The tea industry also helps Sri Lanka's economy by contributing about $15 \%$ of foreign exchange earnings (Central Bank of Sri Lanka, 2018). It explains criticality of the contribution that, any change in the steadiness of performance of the industry can seriously affect the health of Sri Lankan economy.

Quality of life could be defined as an individual's satisfaction with his or her life dimensions compared to his or her ideal life. Quality of life is influenced by an individual's physical and mental health, the degree of independency, the social relationship with the environment, and other factors (Ruzevicius, 2012). Unique feature in plantation human resource management framework compared to other industries is that, it is a blend of conceptual human resource management and best human care practices, not only for direct work-force, but inclusive of wider plantation community (Gamage and Wickramaratne, 2019). Therefore, improving quality of life in entire plantation community has a significant impact on overall performances of the tea estate, since the work-force is totally residential in nature.

The findings of Dishanka and Ikemoto (2014) witnessed that, poor socio-economic conditions of workers and lack of living facilities provided for workers as well as their families have adversely affected the labor productivity. According to the research findings, quality of living conditions of the estate population are wellbelow the conditions attained even by the rural population in Sri Lanka as a result of low household income. The findings further elaborated that, because of low level of health and nutrition, facilities such as housing, sanitation and lack of awareness on household expenditure management of plantation community including workforce, resulted with low household income which in turn negatively affects the worker productivity in the sector (Department of Census and Statistics, 2019). Further studies witnessed the above fact that, care and attention for basic human needs in plantation community played a significant role in building up a productive long-term relationship between management and work-force as major partners in working community within the plantation sector (Gamage and Wickramaratne, 2018). They further stated that, physical quality of life such as health conditions, consumption patterns, working facilities and living conditions, focuses on people's welfare, their living and working conditions which will have direct impact of their attitudes towards work and recreation. Kurihara (2007) argued that, conventional plantation management model is not equipped for serving the basic social needs and it does not respond to improve the level of quality of life in plantation community. On the other hand, there is no possibility for tea plantation workers to improve their living conditions through their ineffective trade unions, that they are not really representing the actual needs of work-force due to uncontrollable political pressure (Yogaratnam, 2010).

In sum, improving the level of quality of life of plantation community has a great impact on improving worker productivity. Roloff (1987) illustrated that, when individuals receive a benefit, they may experience a state of discomfort due to a sense of indebtedness and thus, force them to reciprocate the benefit in order to restore the equilibrium of the interpersonal relationship. This was further emphasized by Redmond (2015) and Rajadurai (2015) that, more investment towards development of socio- economic status of the plantation community and rewards, increases the level of individual's commitment to the employer-employee relationship and ultimately highers productivity.

Quality of work life is a multidimensional approach that is explained by different variables which are related to employment security and satisfaction. According to Swamy et al. (2015), Quality of Work Life (QWL) can be defined as an extent to which an employee is satisfied with personal and working needs through participating in the workplace while achieving the goals of the organization. There are so many drivers which can elaborate and explain the quality of work-life such as 
rewards, job security, and career growth opportunities (Lau, Wong, Chan and Law, 2001), healthy and secure work environment, salary and benefits, job security, autonomy at work, providing the basis for skills education, and determining the job development direction (Talebi et. al., 2012), a few to mention. However, there are many other critical factors which contribute to QWL, including physical, physiological and social factors (Swamy et al., 2015).

Tea plantations are not merely economic and commercial production units, but rather complete and total social institutions. It is clearly executed that, workers and their lives are bound with the work-life and the management responsibility on providing the living facilities (International Tea Committee-ITC, 2015). Going beyond, employees are expecting favorable worklife environment from the management such as transparent way of goal setting and performance evaluation, benefits, rewards and recognition, job security, training opportunities, transformation of new knowledge and sharing facilities, career development and succession, as key components (Gamage and Wickramaratne, 2018; Gamage and Wickramaratne, 2019). This was well supported with the research findings of Rose et al. (2006) that, favorable working environment which gives employees a fair and transparent succession, career growth and advancement as well as career satisfaction will have a significant impact on the quality of work-life and ultimately increases the worker performance. Further research findings of Elamparuthi (2014) stressed that training and development, knowledge transformation and employment opportunities linked with skills and employee motivation by way of performance based rewards have comparatively a higher impact on enhancing the level of quality of work-life. This was well supported with the findings of Anwar et al., 2013; Reddy and Reddy, 2014; Swamy et al., 2015 that, human capacity development opportunities, health and safety work environment, career planning and well-being initiatives of employees will lead to enhance the status of QWL.

With the higher level of QWL, employee satisfaction will increase while motivated employees will produce more outputs and greater performance. Swamy et al. 2015 stressed that, focusing on improving QWL to increase the contentment and satisfaction of employees can result in various advantages for both employees and organization. They further added that, higher level of QWL ensures the full usage of a worker's potential by assuring greater involvement which makes the work more effective and efficient while end up with higher level of productivity. Higher levels of employee productivity provide various advantages for the organizations as well as for the employees such as higher profitability and maximize organizational competitive advantage by reducing cost of production and in other way round by improving the quality of output (Baily et al., 2005; Hill, Jones and Schilling, 2014).

This fundamental argument is almost applicable to tea plantation industry as well. Perera (2017) stressed that, level of productivity in tea plantations can be improved by reducing the cost or increasing output. The labor cost is the highest cost component in tea plantations, which represents approximately $67-70 \%$ of total production cost (Perera, 2017; Central Bank of Sri
Lanka, 2018; Gamage and Wickramaratne, 2019). In order to sustain the tea industry positively to gain competitive advantage in the global market, cost of worker has to be reduced. There are several approaches to achieve this goal, but most practical way forward is by increasing the productivity level of workers. Previous research findings supported the fact that, increasing the level of QWL will increase the level of worker productivity.

\section{Research Methodology}

\section{Method and Procedure of Data Aollection}

The study adopted a qualitative approach, which depends on responses of one-on-one un-structured interviews with operational level workers by the use of an interpreter for better communication while avoiding barriers on the native language of tea plantation workers. Qualitative research methodology was adopted to get a better understanding through actual conversations and to identify trends and opinions related to selected research topic. Ultimate focus of interviews was to identify and cluster the best human care practices and knowledge management practices as sustainable Human Resource Management Practices. The sample included 100 operational workers who are presently working in tea plantations as tea harvesters belonging to three reputed regional plantation companies in Sri Lanka. The selection was based on simple random sampling and three companies were selected according to the comparative performance of Regional Plantations Company (RPC) ranking by Ceylon Tea Traders Association (CTTA). The selection process for tea harvesters was purely based on their experience in the tea industry. The reliability of the information was assured by repeating the questions for same information on different patterns and collected information was supported with the findings from multiple sources such as industry related research papers, publications, articles and participatory observations. Average duration of each interview was 30 minutes including time allocation for their further clarifications and open views. In order to conduct the interviews for 100 tea harvesters allocating 30 minutes per participant, ten human development officers working in tea plantations with fluent native language were selected and they were initially trained as interviewers to assist on conducting the interviews.

The questionnaire was divided in to two main sections, part one for general and biographical information about the participants such as their age, number of years' experience in plantations and experience in current estate and designation. The questions in part two were based on to elaborate their views on best human care and knowledge management practices, relationship of these human care and knowledge management practices towards quality of life (QL) and quality of work-life (QWL) as well as towards enhancing the worker productivity in tea plantation industry. The participants were asked to prioritize human care and knowledge management practices according to the relative importance. Such human care practices were clustered during questionnaire development stage on the pre-determined categories by considering practical applications in the industry and by considering the authors' previous research findings (Gamage and 
Wickramaratne, 2018; Gamage and Wickramaratne, 2019). Also, knowledge management practices were grouped considering the core steps in knowledge management cycle (Evans et. al., 2014). The current study on operational workforce is purely to further verify, prioritize and validate the identified best human care and knowledge management practices.

\section{Theoretical Framework}

The worker productivity level in tea industry has direct relationship between human care best practices and knowledge management practices as sustainable HR practices. The foundation of the proposed human resource management model in tea plantation industry is based on two pillars:

- Smooth execution of the process of enhancing the worker productivity is based on the best human care practices.

- Continuation of the process of sustaining higher level of worker productivity is based on the best knowledge management practices.

Global tea market is estimated to be approximately US \$ 73.13 in 2024 (Hilal, 2020) and the other hand competitiveness of the Sri Lanka's tea is declining in the global market (Gamage and Wickramaratne, 2019). The issue related to competitiveness of Sri Lanka's tea is mainly because of the productivity parameters whereas low productivity and high cost of production in Sri Lanka's tea is key features identified, compared to other global competitors such as Kenya, China and India (Perera, 2017; Silva, 2018). Competitive advantage achieved compared to Sri Lanka's potential is far behind and this has created serious issues for sustainability of the industry (Gamage and Wickramaratne, 2019). Therefore, sustainable development of the tea industry should be based on sound and competent human resource base. Authors are proposing that, the theoretical model developed is expected to make a unique contribution by incorporating best human care practices and knowledge management practices in enhancing employee productivity.

The proposed model is based on the proposition of psychological contract and social exchange theories. Psychological contact theory, introduced by Argyris (1960) suggests that, the relationship between employer and employee is not mainly for formal contract for economic benefits, but it is beyond the expectations of such benefits and more towards to social relationship. In the context of employee-employer relationship, reciprocal obligations are set in manner as a mutual contact (Rousseau, 1989) and reciprocal psychological contract between employer and employee (Buunk and Schaufeli, 1999). Gamage and Wickramaratne (2019) further argued that, the notion of psychological contract refers to the expectations held by employees about the nature of their exchange with the organization. The social exchange theory, explained by Blau (1964), which involves unspecified obligations such as if one person does another a favor expecting a benefit in future as a return. Social exchange theory is one of the most enduring and widely used conceptual frameworks
(Cropanzano et al., 2017) to explain the social relationship between employer and employee in work environment. The social exchange process begins when a supervisor or coworker treats the individual in a positive or negative manner (Eisenberger et al., 2004) and in return, the target, often a subordinate or coworker, may then choose to reciprocate this treatment with good or bad behavior (Eisenberger et al., 1987). In organizational context, treating employees in a positive manner will add value to the performance of the organization by increasing their level of productivity.

Therefore, by applying these two theories, quality of work-life and quality of life of employees in tea plantations will enhance through human care and knowledge management best practices. In return, the employees will develop a sense of obligation to reciprocate by increasing their levels of productivity.

\section{Research Model}

The research model is indicated below in Figure 1. Sustainable human resources (HR) practices including human care practices and knowledge management practices, quality of work-life, quality of life and worker productive are listed as the factors in Figure 1.

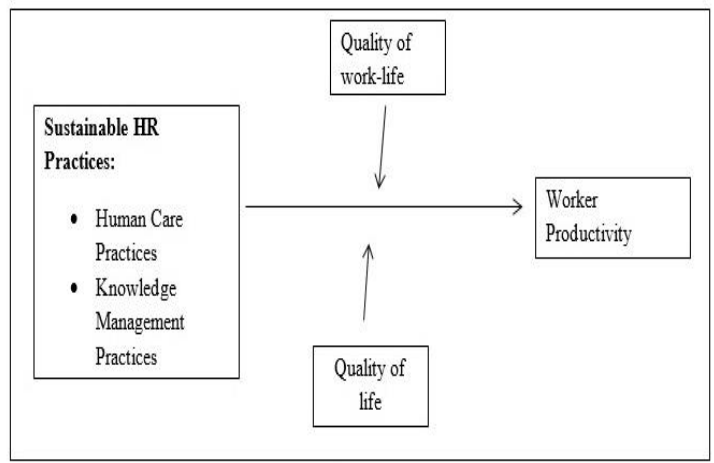

Figure 1. Research Model

Source: Authors' own compilation

\section{Data Analysis}

The best human care and knowledge management practices identified and clustered according to authors' previous studies (Gamage and Wickramaratne, 2018; Gamage and Wickrameaatne, 2019) have been checked for further validation on industry applicability in operational level work-force, which is a more vital and critical human resource segment in tea plantation industry in terms of overall productivity. The following best human care and knowledge management practices were identified as the most important sustainable HR practices, which have comparatively a higher impact on improving worker productivity in tea plantations.

Analyzing the feedback received from operational workforce who are working in tea estates under well reputed regional plantation companies elaborated that, the identified best human care and knowledge management practices have a direct impact on enhancing worker productivity levels of tea plantation industry in 
Sri Lanka. They further stressed that, employee motivation level will increase by applying these best HR practices which will help to enhance their existing levels of quality of work-life (QWL) and quality of life (QL). The favorable environment developed through higher levels of QWL and QL will help employees to produce more in terms of outputs and enhance their performance. This has a great impact on enhancing worker productivity indicators such as intake per harvester, yield and cost per worker.

HRM model proposed for tea industry explained the direct relationship of human care and knowledge management practices as sustainable human care practices with worker productivity. Findings further expressed the relationship between best human care and knowledge management practices with QWL and QL. It is revealed that, QWL and $\mathrm{QL}$ act as mediators to stimulate and enhance the direct relationship between sustainable HR practices and worker productivity. Sustainable human care practices as the perspectives of plantation operational workforce are indicated in Table 1.

Table 1: Sustainable Human Care Practices

(Perspectives of Plantation Operational Workforce)

\begin{tabular}{|l|l|}
\hline & Sustainable Human Care Practices \\
\hline $\mathbf{1}$ & Living Environment \\
\hline & Proper housing facilities \\
\hline & Proper and adequate sanitary facilities \\
\hline & Plean water facilities \\
\hline & Proper access roads \\
\hline $\mathbf{2}$ & Health and Nutrition \\
\hline & $\begin{array}{l}\text { Initiatives for minimizing anemic cases / zero } \\
\text { anemia programs }\end{array}$ \\
\hline & Maternal care practices \\
\hline & Child care practices \\
\hline $\mathbf{3}$ & Periodic medical tests \\
\hline & Safety and Protection \\
\hline & Adequate safety \& protection staff \\
\hline & Sufficient safety \& protection equipment \\
\hline & Necessary training for safety \& protection \\
\hline $\mathbf{4}$ & Employee Capacity Building \\
\hline & Promoting savings within plantation families \\
\hline & $\begin{array}{l}\text { Providing micro finance facilities for self- } \\
\text { employment opportunities as an additional income } \\
\text { source }\end{array}$ \\
\hline & $\begin{array}{l}\text { Training and awareness of savings and household } \\
\text { cash management }\end{array}$ \\
\hline $\mathbf{5}$ & Education and Development \\
\hline & $\begin{array}{l}\text { Providing scholarships for needy children to } \\
\text { complete their education and higher education } \\
\text { suitable opportunities }\end{array}$ \\
\hline $\mathbf{6}$ & $\begin{array}{l}\text { Moving away from the conventional recruitment } \\
\text { process to capture young talent into suitable }\end{array}$ \\
\hline & Youth empowerment \\
\hline & estates \\
\hline & Araining and guiding youth in plations for \\
\hline &
\end{tabular}

Source: Authors' own compilation
Table 2: Sustainable Knowledge Management Practices (Perspectives of Plantation Operational Workforce)

\begin{tabular}{|c|c|}
\hline & Sustainable Knowledge management practices \\
\hline \multirow[t]{4}{*}{1} & Collection and Capturing \\
\hline & $\begin{array}{l}\text { High tech and Information Technologies (IT) for } \\
\text { capturing sensitive data }\end{array}$ \\
\hline & $\begin{array}{l}\text { Transparent communication tools irrespective of } \\
\text { the language }\end{array}$ \\
\hline & $\begin{array}{l}\text { Promoting formal and informal discussions within } \\
\text { employees and groups }\end{array}$ \\
\hline \multirow[t]{4}{*}{2} & Classifying, organizing and storing \\
\hline & $\begin{array}{l}\text { Use of new technology for data classifying and } \\
\text { storing }\end{array}$ \\
\hline & $\begin{array}{l}\text { Implementing methods of new technology for } \\
\text { information }\end{array}$ \\
\hline & Central information access \\
\hline \multirow[t]{5}{*}{3} & Sharing and Dissemination \\
\hline & $\begin{array}{l}\text { Introducing peer training methods and on the job } \\
\text { training (OJT) initiatives }\end{array}$ \\
\hline & IT based online systems for knowledge sharing \\
\hline & $\begin{array}{l}\text { E-leaning facilities in addition to more learning } \\
\text { and development opportunities in e-platforms }\end{array}$ \\
\hline & $\begin{array}{l}\text { Promoting internal training expertise for more } \\
\text { training opportunities }\end{array}$ \\
\hline \multirow[t]{4}{*}{4} & Accession, Usage and Review \\
\hline & $\begin{array}{l}\text { Introducing digital platforms for easy access to } \\
\text { information and knowledge }\end{array}$ \\
\hline & Periodic internal reviews \\
\hline & $\begin{array}{l}\text { System implementation for access to knowledge } \\
\text { by experience }\end{array}$ \\
\hline \multirow[t]{5}{*}{5} & Value Creation \\
\hline & More training opportunities based on actual needs \\
\hline & $\begin{array}{l}\text { Facility to exchange and get the knowledge from } \\
\text { internal training experts within the company }\end{array}$ \\
\hline & $\begin{array}{l}\text { Reward system linked with knowledge } \\
\text { management process within the company }\end{array}$ \\
\hline & $\begin{array}{l}\text { Recognition and appreciation for innovations and } \\
\text { creativity within the estate }\end{array}$ \\
\hline \multirow[t]{5}{*}{6} & Sustainability \\
\hline & $\begin{array}{l}\text { Promoting advancement and higher education } \\
\text { opportunities }\end{array}$ \\
\hline & $\begin{array}{l}\text { Providing exposure to advancement and new } \\
\text { knowledge }\end{array}$ \\
\hline & $\begin{array}{l}\text { Recruitment process linked to education and } \\
\text { talents }\end{array}$ \\
\hline & $\begin{array}{l}\text { Developing talent pool within the industry and } \\
\text { linking them with succession plan }\end{array}$ \\
\hline
\end{tabular}

Source: Authors' own compilation

\section{Findings and Discussion}

The findings of this study were supported with the theories and models developed through various research. Referring to the previous research findings, sustainable HR practices such as best human care and knowledge management practices have a direct impact on the worker 
productivity, which is clearly elaborated in studies related to psychological contact and social exchange theories.

In respect of plantation industry, workforce in plantations receive various benefits such as housing, health and wellbeing facilities, medical care, sanitation and community development programs as human care practices. Furthermore, intangible benefits such as training and development programs, skills development, knowledge sharing sessions and capacity building programs as knowledge management practices are critical. In order to reciprocate the benefits they gained, workers will increase their level of performance and produce more outputs. Once the workers are experiencing the benefits they gained from these best $\mathrm{HR}$ practices, their level of quality of life (QL) and quality of work-life (QWL) will improve. This will again add value to increase the level of performance by increasing employee motivation, commitment and engagement.

Leitão et. al. (2019) stressed that, quality of life is modulated by a wide range of factors, such as psychosocial parameters, health conditions, well-being in the workplace, the adequacy of working resources and infrastructures. This fact was well supported by the findings of Yuh and Choi (2017) that, significant productivity improvement can be observed due to subjective components such as trust, commitment and satisfaction of employees. Also Lodha and Pathak (2017) as well as Gamage and Wickremeratne (2019) revealed the same findings. Implementing best HR practices in an organization will increase the level of employee motivation and engagement, which will add value for the level of efficiency and ultimately have impact on the productivity. Further studies highlighted the relationship between psychological contract and the employee engagement as well as the impact on worker productivity (Irvine, 2009; Bal et al, 2013; Lodha and Pathak, 2017; Gamage and Wickremeratne, 2019). The above fact on employee commitment and productivity was discussed in studies by Meyer and Allen (1997) as well as Meyer et al. (2002). Successful reciprocal exchange between employer and employee may transform the relationship into a high-quality social exchange relationship and people may become affectively committed to organizations for increasing the impact on overall performance. Omotayo (2015) elaborated the relationship between knowledge management and worker productivity as a sustainable approach. He further stated that, less care on managing knowledge within an organization will lead to demise of the organization due to poor productivity levels. Scholars argue that, knowledge is created and held collectively. People learn and create knowledge through continuous social interaction (Nonaka and Peltokorp, 2006). In simple, knowledge management process can be used as a social interaction tool within the organization and may finally enhance the performance. In terms of plantations, knowledge management process can be used effectively to increase the interaction among the employees for transferring and having a good blend of new as well as advanced knowledge with experience. Finally, this approach will have a higher impact on worker productivity improvements.
The research provides some important implications to policy makers in the tea industry considering the research findings. It is with evidence that, to improve the level of productivity in tea plantations, the employees should be facilitated with best human care practices in areas such as living environment, health \& nutrients, safety \& protection, employee capacity building, education \& development and youth empowerment. Also, the best knowledge management practices such as capturing, classifing and storing important knowledge, knowledge sharing, knowledge access \& usage, knowledge value creation and sustainability should be inculcated within the tea plantations for worker productivity improvement.

There is a limitation of generalizing these findings into an entire tea plantation industry. These findings are based on a sample size of 100 operational workers (harvesters) working in tea plantations of Sri Lanka. The research findings should be further investigated by conducting a survey based on a comparatively larger sample representing large number of tea estates in the country. The same study should be repeated in other tea growing countries to generalize the findings for an entire tea industry in global context.

\section{Conclusion}

In the current context of declining worker level and the firm level productivity, the conventional HRM practices do little to turnaround the tea plantation sector in Sri Lanka. Therefore, this qualitative study was conducted with the purpose of proposing human care and knowledge management practices to promote worker productivity. Based on the premise of social exchange and psychological contract theories, the study proposed a human resource model aimed at enhancing the worker productivity. The model proposed by this research as a sustainable human resource management model for tea plantation industry stresses that, best human care and knowledge management practices act as sustainable HR practices in tea industry and these factors determine the productivity of tea estate workers. This model will act as a value addition to the contemporary HRM models applied and practiced in various industries.

\section{References}

Anwar, A. M., Mahmoud, K. A., Rusinah, S. and Ahmad, S. M. A. (2013). The Drivers of Quality of Working Life (QWL): A Critical Review, Australian Journal of Basic and Applied Sciences, Vol.7(10), 399-402.

Argyris, C. (1960). Understanding organizational behavior. Dorsey Press, Homewood, IL.

Baily, M. N., Farrell, D., Greenberg, E., Henrich, J. D., Jinjo, N., Jolles, M., and Remes, J. (2005). Increasing global competition and labor productivity: Lessons from the US automotive industry. McKensie Global Institute. 
Bal, P., Kooij, D., and DeJong, S. (2013). How do developmental and accommodative HRM enhance employee engagement and commitment? The role of psychological contract and SOC strategies. Journal of Management Studies, 50(4), 546-572.

Blau, P.M. (1964). Exchange and power in social life. Social Forces, 44(1), 128-129. Retrieved from https://doi.org/10.2307/2574842.

Buunk, B.P. and Schaufeli, W.B. (1993). Burnout from a social comparison perspective. In W.B. Schaufeli, C. Maslach, T. Marek (Eds). Professional Burnout: Recent Developments in Theory and Research, 53-69. Washington: Taylor \& Francis.

Census of Population and Housing Survey (2019). Department of Census and Statistics, Ministry of Finance and Planning.

Central Bank of Sri Lanka. (2018). Annual Report. Colombo: Central Bank of Sri Lanka.

Dishanka S. and Ikemoto, Y. (2014). Social Development and Labour Productivity: The Problem and a Solution for the Tea Plantation Sector of Sri Lanka, International Journal of Theory \& Practice, Vol. 05, No. 01, 67-80.

Elamparuthi, S. J. (2014). Significance of Quality of Work Life in Small Scale Industries, Employees in Cuddalore, European Journal of Commerce and Management, Research Vol. 3, Issue: 1, 17-26.

Evans, M., Dalkir, K., and Bidian, C. (2014). A holistic view of the knowledge life cycle: the knowledge management cycle (KMC) model. Electronic Journal of Knowledge Management, 12(2), 85-97.

Eisenberger, R., Lynch, P., Aselage, J and Rohdieck, S. (2004). Who Takes the most Revenge? Individual Differences in Negative Reciprocity Norm Endorsement. Personality \& social psychology bulletin. $30 . \quad 787-99$. $10.1177 / 0146167204264047$.

Eisenberger, R., Cotterell, N., and Marvel, J. (1987). Reciprocation ideology Journal of Personality and Social Psychology,53, 743-750.

Forbes and Walker Tea Review (2019). Forbes and Walker Tea brokers, Colombo, Sri Lanka.

Gamage, A.T. and Wickramaratne, W.P.R. (2018). Towards A Sustainable HRM Model for Human Productivity in Tea Industry: An Empirical Study of Tea Plantation Sector In Sri Lanka: 13th International Research Conference on Management and Finance 2018, University of Colombo.
Gamage, A.T. and Wickramaratne, W.P.R. (2019). Productivity Enhancing Sustainable Human Care and Knowledge Management Practices in Sri Lankan Tea Industry: International Journal of Business and Social Science, Vol. 10, 74-82. No. 8, doi:10.30845/ijbss.v10n8p9.

Hilal, M.I.M. (2020). Sri Lanka's Tea Economy: Issues and Strategies, Journal of Politics and Law, Vol. 13, No. 1, 1-11.

Hill, C., Jones, G., and Schilling, M. (2014). Strategic management: theory: an integrated approach. Cengage Learning.

International Tea Committee (ITC) (2015). Annual bulletin of statistics. ITC, London http://www.fao.org/3/a-i6583e.pdf

Irvine,D.(2009). Bloomberg Business Week Official Website.

http://www.businessweek.com/bwdaily/dnflash /content/may2009/db2009058_952910.htm

Jayawardena, K. (1984). The plantation sector in Sri Lanka: Recent changes in the welfare of children and women. World Development, 12(3), 317-328. doi:10.1016/0305$750 \mathrm{X}(84) 90067-6$

Kelegama, S. (2010). Productivity Decline in the Tea Plantations and a Possible Way Forward. Colombo: VijithaYapa Publications.

Koththagoda, K.C. and Dissanayake,D.M.R. (2017). Potential of Tea Tourism in Sri Lanka: A Review on Managerial Implications and Research Directions, Equality and Management, University of Szczecin, Poland, 51-68.

Kurihara, S. (2007). The estate plantation community in NuwaraEliya district of Sri Lanka: An introductory overview of social issues and poverty among residents living under the conventional plantation system. Yokohama Journal of Social Sciences, 15, 123-129.

Lahiri, S. (2000). Bonded labour and the tea plantation economy. Revolutionary Democracy. 6 (2). Retrieved from http://www.revolutionarydemocracy.org/rdv6n 2/tea.htm

Lau, T., Wong, Y.H., Chan, K.F. and Law, M., (2001). Information technology and the work environment: Does it change the way people interact at work? Human Systems Management, Vol. 20(3), 269- 274.

Leitão J., Pereira D. and Gonçalves Â., (2019). Quality of Work Life and Organizational Performance: Workers' Feelings of Contributing, or Not, to the Organization's Productivity. Int. J. Environ. Res. Public Health., 16(20), 3803. doi:10.3390/ijerph16203803 
Lodha, D. and Pathak, K. (2017). Effect of psychological contract on employee engagement. Journal of Researchers, 1(1), 6-9.

Meyer, J. P., Stanley, D. J., Herscovitch, L. and Topolnytsky, L. (2002). Affective, continuance, and normative commitment to the organization: A meta-analysis of antecedents, correlates, and consequences. Journal of Vocational Behavior, 61(1), 20-52. https://doi.org/10.1006/jvbe.2001.1842

Meyer, J. P. and Allen, N. J. (1997). Advanced Topics in Organizational Behavior: Commitment in the workplace: Theory, research, and application Thousand Oaks, CA: SAGE Publications, Inc. doi: $10.4135 / 9781452231556$

Munasinghe, M., Deraniyagala, Y., Dassanayake, N., and Karunarathna, H. (2017). Economic, social and environmental impacts and overall sustainability of the tea sector in Sri Lanka. Sustainable Production and Consumption, 12, 155-169.

Mwaura, F. and Muku, O. (2007). Tea Farming Enterprise Contribution to Smallholders' Well Being In Kenya, Tea Research Foundation of Kenya, AAAE Conference Proceedings (2007) 307-313.

Nonaka, I. and Peltokorpi, V. (2006). Objectivity and subjectivity in knowledge management: A review of 20 top articles. Knowledge and Process Management. 13. 73-82.

Omotayo, F.O. (2015). Knowledge management as an important tool in organizational management: A review of literature. Library Philosophy and Practice (e-journal). 1238. Retrieved from http://digitalcommons.unl.edu/libphilprac/1238

Oxford Business Group (2016). Growth prospects for Sri Lanka's tea industry. Oxford Business Group. http://www.oxfordbusinessgroup.

Perera, M. (2017). Sri Lanka tea plantations: Crisis and restructure, Business Times, The Sunday Times, January 15, 2017.

Rajadurai, R. (2015). Determinants of Annual Productivity of Female Tea Harvesters in the Mid Country Regional Plantation Company Estates in Sri Lanka. Peradeniya: Post Graduate Institute of Agriculture.

Reddy, D. M. L. and Reddy P, D. M. (2014). Comparative analysis of quality of work life among public and private sector bank employees. International Journal of Organizational Behaviour \& Management Perspectives, 2(4), 644-647.
Redmond, M.V. (2015). Face and politeness theories. English Technical Reports and White Papers. $2 . \quad$ Retrieved from http://lib.dr.iastate.edu/engl_reports/2

Roloff, J. (1987). Learning from multi-stakeholder networks: Issue-focused stakeholder, management. Journal of Business Ethics, 82(01), 233-250.

Rose, R. C., Beh, L., Uli, J. and Idris, K. (2006). Quality of work life: implications of career dimensions. Journal of Social Sciences, 2(2).

Rousseau, D. (1989). Psychological and implied contracts in organizations. Employee Responsibilities and Rights Journal, 2(2), 121139.

Ruževičius, J. (2014). Quality of Life and of Working Life: Conceptions and Research, 17th ToulonVerona International Conference, Liverpool John Moores University, England, August 2829, 2014.

Savarimuthu, A. and Rachael, A.J. (2017). Psychological Contract- A Conceptual Framework. International Journal of Management, 8 (5), 2017, 101-108. Available from: https://www.researchgate.net/publication/3215 74803

Silva, G. (2018). Targeted Policies for Production and Export Diversification - Sri Lankan Case Study, 10th Multi-year expert meeting on commodities and development, United Nations Conference on Trade and Development, 25-26 April 2018, Geneva.

Swamy, D.R., Nanjundeswaraswamy, T.S. and Rashmi, S. (2015). Quality of Work Life: Scale Development and Validation, International Journal of Caring Sciences, May-August 2015, Volume 8 Issue 2, 281-300.

Talebi, B., PakdelBonab, M., Zemestani, G. and Aghdami, N., (2012). Investigating the Relationship between the Employee's Quality of Work Life (QWL) and Their Effectiveness in Banking. European Journal of Experimental Biology, 2(5): 1840-1841. Available from: https://www.researchgate.net/publication/3157 28630

Wal, S. V. D. (2008). Sustainability Issues in the Tea Sector, A comprehensive Analysis of Six Leading Producing Countries, Centre for Research on Multinational Corporations, Amsterdam, Netherlands.

Yogarathnam, N. (2010). Economics of scale ineffective in Lankan Tea Business. Daily News, 6.

Quality of Life and Quality of Work Life as Determinants of Employee Productivity: Self-reports of Tea Harvesters in Sri Lanka 
Yuh, J. and Choi, S. (2017). Sources of social support, job satisfaction, and quality of life among childcare teachers. The Social Science Journal. 54. 10.1016/j.soscij.2017.08.002 